\title{
Latest development in microalgae-biofuel production with nano-additives
}

Nazia Hossain ${ }^{1 *} \mathbb{B}$, T. M. I. Mahlia ${ }^{2}$ and R. Saidur ${ }^{3,4}$

\begin{abstract}
Background: Microalgae have been experimented as a potential feedstock for biofuel generation in current era owing to its' rich energy content, inflated growth rate, inexpensive culture approaches, the notable capacity of $\mathrm{CO}_{2}$ fixation, and $\mathrm{O}_{2}$ addition to the environment. Currently, research is ongoing towards the advancement of microalgalbiofuel technologies. The nano-additive application has been appeared as a prominent innovation to meet this phenomenon.

Main text: The main objective of this study was to delineate the synergistic impact of microalgal biofuel integrated with nano-additive applications. Numerous nano-additives such as nano-fibres, nano-particles, nano-tubes, nanosheets, nano-droplets, and other nano-structures' applications have been reviewed in this study to facilitate microalgae growth to biofuel utilization. The present paper was intended to comprehensively review the nano-particles preparing techniques for microalgae cultivation and harvesting, biofuel extraction, and application of microalgae-biofuel nano-particles blends. Prospects of solid nano-additives and nano-fluid applications in the future on microalgae production, microalgae biomass conversion to biofuels as well as enhancement of biofuel combustion for revolutionary advancement in biofuel technology have been demonstrated elaborately by this review. This study also highlighted the potential biofuels from microalgae, numerous technologies, and conversion processes. Along with that, the study recounted suitability of potential microalgae candidates with an integrated design generating value-added co-products besides biofuel production.

Conclusions: Nano-additive applications at different stages from microalgae culture to end-product utilization presented strong possibility in mercantile approach as well as positive impact on the environment along with valuable co-products generation into the near future.
\end{abstract}

Keywords: Microalgae, Microalgal biofuel, Nano-additives, Bioenergy, Biodiesel

\section{Background}

Biofuel has caught substantial attention worldwide nowadays as an alternative fuel due to its capability to adapt with gasoline for a maximum $85 \%$ blend without any engine modification. Subsequently, the suitability of various candidates for biofuel is being continuously quested by the researchers and environmentalists [1-5]. In this recent era, one of the most sophisticated technologies, nano-technology integration with bioenergy application by the nano-energy sector has brought a revolutionary

\footnotetext{
*Correspondence: bristy808.nh@gmail.com

${ }^{1}$ Department of Civil and Infrastructure Engineering, School

of Engineering, RMIT University, Melbourne, VIC 3001, Australia

Full list of author information is available at the end of the article
}

impact on biofuel conversion processes and enhancement of engine performances. Nano-technology is defined as designing a device or material in nano-scale $\left(10^{-9} \mathrm{~m}\right)$. To accelerate the biofuel yield and improve the efficiency of biofuel utilization in petrol and diesel, nanotechnology has been initiated via nano-additives such as nano-magnets, nano-crystals, nano-fibres, nano-droplets, and others [6-8]. Figure 1 presents the perspectives of nano-additives on microalgae cultivation to microalgal-biofuel implementation.

On this eve of the quest for suitable biomass for biofuel, the concept of microalgae cultivation appeared to the spotlight for biofuel manufacturing due to several positive perspectives such as (i) they do not clash with human or 


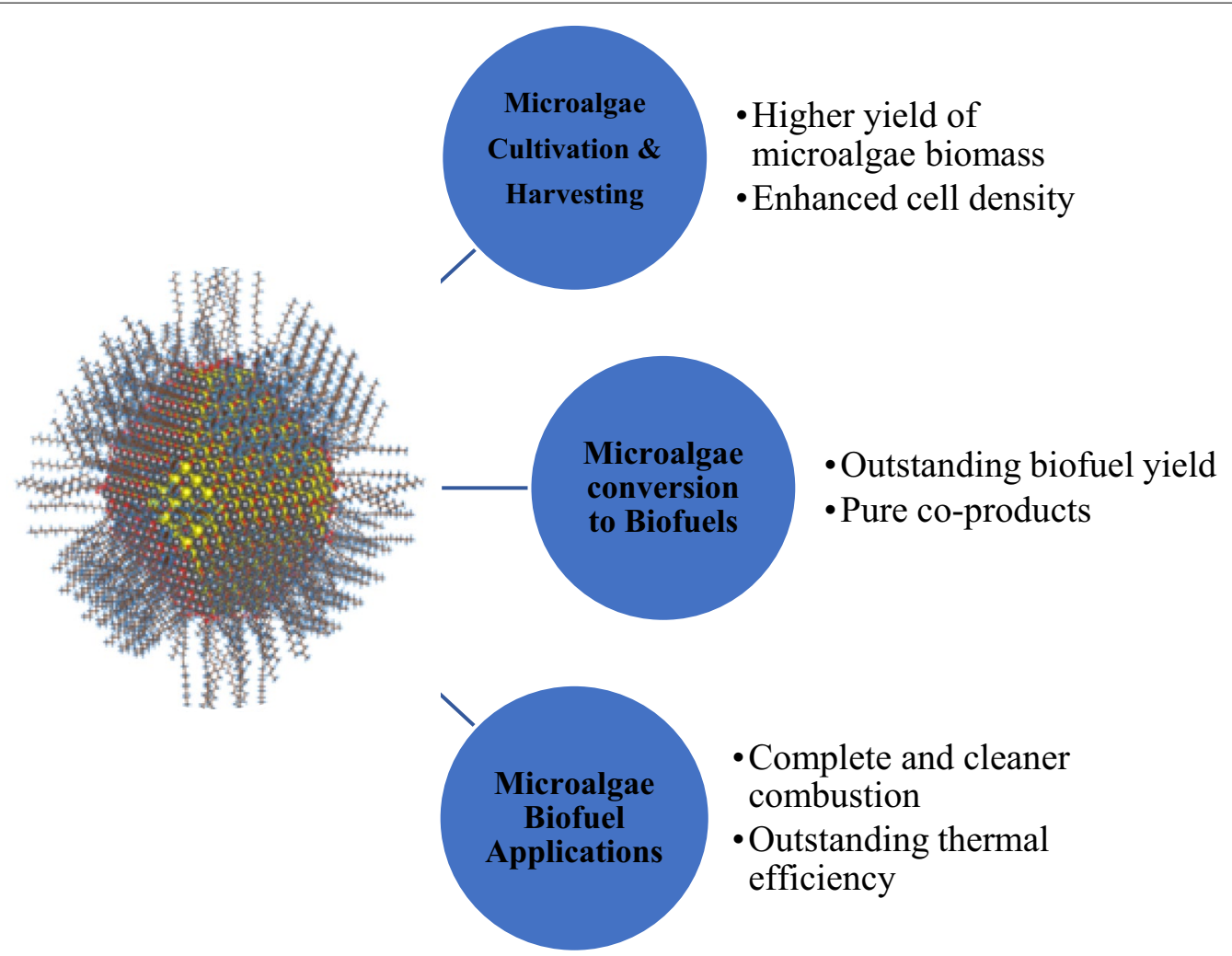

Fig. 1 Nano-additive applications for the enhancement of microalgae cultivation to biofuel implementation

animal food chains, (ii) very rich with carbohydrate, protein, and oil content, (iii) can grow in aqueous media such as wastewater, freshwater, saline water, and assimilate nutrients from brackish water, salt water, or highly polluted water, (iv) demand low water, (v) sustain capability to grow whole year naturally with sunlight presence, (vi) can be cultivated in the waste dump area, sea, ponds, rivers, industrial, and municipal waste drainage, wet bare lands especially in cold regions, (vii) develop sustainable $\mathrm{O}_{2}$ generation system, and (viii) diminish $\mathrm{CO}_{2}$ by up taking it for photosynthesis respiration [9-14]. In addition, microalgae contain very short harvesting life cycle and yield nascent biomass that drives higher productivity of the desired biofuel. Interestingly, microalgae carry a prodigious amount of carbohydrates, protein and lipid, the sole components of biofuel conversion [13, 15-17]. Nano-technology applications have been implemented to biofuel industries, since the existing controversial approaches of traditional microalgae culture-biofuel production contain a number of limitations such as inconsistent industrial-scale microalgae production, high microalgae production and harvesting cost, energy consumption for biofuel production from microalgae, and the increase of greenhouse gas intensity in environmental [18]. Nano-technology applications can be entailed in different stages from microalgae cultivation to microalgae-biofuel application in fuel engines due to durability, recyclability, adsorption efficiency, catalytic performance, stability, crystallinity, economical advantage, high storage capacity, excellent biofuel yield, and environment-friendly characteristics. According to the previous studies, nano-technology application enhanced microalgae cultivation, the maximum yield of numerous microalgae biofuels as well as microalgae-biofuel implications in petrol and diesel engines. Various nano-materials, e.g., nano-fibres, nano-particles, nano-tubes, nano-sheets, and other nano-structures, have been investigated as effective nano-catalysts in direct and indirect approaches in biofuel (e.g., bioethanol, biodiesel, biomethane, and others) yield enhancement [19-22]. For instance, magnetic nano-particles were used as a carrier for enzyme immobilization for bioethanol and biodiesel generation effectively. Owing to high coercivity and powerful paramagnetic characteristics, magnetic nano-particles were also preferred for methanogenesis to produce biomethane [21].

To authors' best knowledge, no review study has been performed on numerous biofuel productions from microalgae integrated with the nano-additive application so far. The closest review with this study was conducted on the bioenergy production from lignocellulosic biomass (agricultural residues), industrial waste (sludge) as well as algae 
(microalgae and macroalgae) with the nano-scale optimization which has merely emphasized on the mechanism of nano-particles, biomass characteristics, and nano-particle application on biomass growth [23]. Compared with that, the current review contextualized the numerous biofuel productions from pure microalgae and optimization with nano-additive application on biomass growth to endproduct application. Therefore, the major objectives of this review work are (i) to determine the array of the techniques and methods associated with nano-particles incorporation with microalgae culture as well as microalgal biofuel, (ii) to demonstrate divergent nano-additive applications on microalgae cultivation, biomass conversion to biofuels, and biofuel combustion, (iii) to identify the potential sources of microalgae, especially the carbohydrate, protein, and lipid-enriched microalgae types for biofuel production and determine the possible microalgae biofuels, biomass conversion technologies, and processes to biofuels, and (iv) to assess the future prospects of the process development planning along with integrated design of some other valueadded products besides biofuel.

\section{General perspective of microalgae}

Microalgae are referred as photosynthetically driven single or multi-cellular living being, the habitat of moist environment either on the solid mud or float on various water types, e.g., fresh water, marine water, wastewater with the presence of sunlight, or artificial light. The scientific consensus is that through photosynthesis respiration, they convert $\mathrm{CO}_{2}$ to $\mathrm{O}_{2}$ and generate large amounts of cellular energy content embedded with sugar, protein, and lipid [24-27].

Nowadays, industrialization and urbanization threaten the existing ecosystem severely by dumping heavy metal waste containing phosphorus, nitrogen, sulfur and others as well as exhaling high amount $\mathrm{CO}_{2}$ to the free air. Another knocking threat to the energy sector is rapid depletion of fossil fuel worldwide due to excessive energy uses [28-30]. With this circumstance, microalgae cultivation in the wastewater, unused fresh, and saline water, drainage is considered as suitable scientific solution for green energy due to some favorable aspects such as multi-functionality, genuine conversion competency biologically and flexibility with growth system, wastewater accumulation, $\mathrm{CO}_{2}$ sequestration, and large amount of carbohydrate-lipid-protein content. To note, carbohydrate-lipid-protein are the main components to generate divergent biofuels (e.g., bio-oil, biodiesel, biobutanol, and others) and biogas (e.g., biohydrogen) [31, 32]. The cellular components of microalgae are composed of huge fraction of lipid, protein, and carbohydrates resulting in the driving factors of biofuel

Table 1 Several potential microalgae species for biofuel production, type, and description of the species in brief [35-42]

\begin{tabular}{|c|c|c|}
\hline Microalgae name & Type & Description in brief \\
\hline Chlamydomonas reinhardtii & Chlorophyta & $\begin{array}{l}\text { Genetically modified by sex-cross, contains high amount of carbohydrate, lipid } \\
\text { and protein in cell wall }\end{array}$ \\
\hline Chlorella sp. & Chlorophyta & $\begin{array}{l}\text { Unicellular green microalgae, source availability of tropical water with enough } \\
\text { solar light }\end{array}$ \\
\hline Spirulina platensis & Chlorophyta & $\begin{array}{l}\text { Spiral-shaped multi-cellular microalgae (with no true nucleus), fresh water } \\
\text { habitant, contains lipopolysaccharides and peptidoglycan (carbohydrate } \\
\text { components) in cell wall as well as cyanophycean and starch are the main } \\
\text { carbohydrate storage products }\end{array}$ \\
\hline Chlorella vulgaris & Chlorophyta & $\begin{array}{l}\text { Spherical shaped, single cellular (with nucleus) microalgae, grows in both fresh } \\
\text { and marine water with adequate sunlight, contains cellulose and hemicellu- } \\
\text { loses (carbohydrate components) in cell wall and starch is the main carbohy- } \\
\text { drate storage product }\end{array}$ \\
\hline Botryococcus braunii & Chlorophyta & $\begin{array}{l}\text { Green microalgae, shape type pyramidal, source availability of tropical and } \\
\text { oligotrophic freshwater such as lakes, ponds, estuaries }\end{array}$ \\
\hline Ostreococcus tauri & Chlorophyta & Eukaryote and unicellular \\
\hline Phaeodactylum tricornutum & Phaeodactylum & Salt water diatoms \\
\hline Nannochloropsis sp. & Heterokont & $\begin{array}{l}\text { Grown in both saline and fresh water, genetically modified and paralleled } \\
\text { recombinant microalgae type }\end{array}$ \\
\hline Symbiodinium sp. & Fungia repanda & Source availability in sea water, advanced eukaryotic, dinoflagellates \\
\hline Phytoplanktons & Either prokaryotic or eukaryotic & $\begin{array}{l}\text { Usually autotrophic, source availability at saline and tropical water sources such } \\
\text { as lakes, ponds with sufficient solar energy }\end{array}$ \\
\hline Cyanobacterial Mats & Prokaryotic & Easily grown in saline water \\
\hline Saccharinajaponica & Brown type of microalgae & Grown at sea and coastal water sources \\
\hline Chlorococum sp. and Spirogyra sp. & Cyanobacteria/blue-green algae & $\begin{array}{l}\text { Shape type spiral, source availability in usually moist environment, marine and } \\
\text { fresh water sources, grown randomly in tropical areas where sunlight is avail- } \\
\text { able sufficiently }\end{array}$ \\
\hline
\end{tabular}


Table 2 Approximate carbohydrate-protein-lipid-ash content composition of suitable microalgae species (dry weight) for biofuel production [32, 43-45]

\begin{tabular}{|c|c|c|c|c|}
\hline Type of microalgae & Total sugars (\%) & Protein (\%) & Lipids (\%) & $\begin{array}{l}\text { Others (including } \\
\text { ash content) \% }\end{array}$ \\
\hline Chlamydomonas reinhardtii & 48 & 17 & 21 & 14 \\
\hline Chlorella sp. & 56 & 22 & 19 & 3 \\
\hline Spirogyra sp. & 20 & 55 & 16 & 9 \\
\hline Porphyridium cruentum & 35 & 50 & 11 & 4 \\
\hline Spirulina platensis & 60 & 12 & 8 & 20 \\
\hline Dunaliella salina & 57 & 32 & 6 & 5 \\
\hline Bellerochea sp. & 3 & 24 & 15 & 3 \\
\hline Chaetoceros sp. & 2 & 18 & 18 & 3 \\
\hline Rhodomonas sp. & 9 & 74 & 15 & 2 \\
\hline Scenedesmus sp. & 18 & 56 & 12 & - \\
\hline
\end{tabular}

production. Table 1 presents some well-known potential microalgae candidates for biofuels. These species were extensively researched in the laboratory and largescale applications so far. Type and description of these species have been tabulated to present a detailed view of selected species, suitable growth conditions (such as water type and region for cultivation), availability, and cellular specifications. Table 2 represents prime microalgae cellular component composition of several wellknown microalgae species for biofuel production [24, 33, 34].

\section{Biofuels from microalgae}

Numerous biofuels, e.g., bioethanol, biodiesel, biooil, biomethane, bio-hydrogen, and others, have been extracted from microalgae [46, 47]. Nano-particles' incorporation with microalgae cultivation (e.g., cell suspension, cell separation, and cell harvesting), biofuel conversion technologies, and biofuel application have amplified the overall yield in every stage [22]. According to the previous studies, a very small amount of colloidal hydrous iron(III) oxide particles boosted almost 100\% microalgae cell suspension; magnetic particles incorporated with aluminum sulfate were very effective for cell separation from the mixed culture of Anabaena and Aphanizomenon microalgae species; silver nano-particles application on Chlamydomonas reinhardtii and Cyanothece 51142 microalgae harvesting increased 30\% higher biomass productivity; and calcium-oxide nano-particles escalated the large-scale biodiesel conversion yield up to $91 \%$ via catalytic transesterification $[18,22,48]$. This study summarized the overall microalgae cultivation integrated with nano-particles until biofuel production in Fig. 2. Different biofuels from microalgae and conversion processes are diagrammed in Table 3.

\section{Preparing techniques of nano-additives for microalgae biofuel}

Magnetic nano-particle (NP) powder has been enumerated to the microalgae cell suspension in the photobioreactor cultivation process to flocculate cells for uniform distribution of nutrients and light all over the reactor. Immunomagnetic detection and modification of microalgae cell by NPs are another well-practiced method for cell suspension enhancement. Nano-liquid has been injected to the cell culture for microalgae harvesting and bio-separation through this technique. Silver nanomaterials have also been implemented on the photobioreactor surface coating for higher light accessibility [22]. Along with microalgae culture and harvesting, sphere nano-particles have been enacted during hydrolysis, lipid extraction, transesterification, and biofuel purification from microalgae via irradiation and ultra-sonication methods and much higher biofuel yield have been obtained. Another established method of nano-materials application includes enzymatic nano-catalyst, lipase carrier. The reactant diffusion rate enhancement by the NPs to the active side of lipase has been determined by Eq. 1 [55]:

$$
R_{\mathrm{df}} \propto \frac{1}{D^{2}}
$$

where $R_{\mathrm{df}}=$ diffusion rate to the active sides of lipase and $D=$ diffusion path diameter of reactant to the access of lipase active side.

NPs for biofuel doping can be formulated by either physical or chemical methods. For instance, plasmaarcing, sol-gel method has been presented as chemical method and ball mill process (agitation rate: $450 \mathrm{rpm}$ ) was presented as a physical method for NPs' preparation in the previous studies [56-58]. Subsequently, NPs 


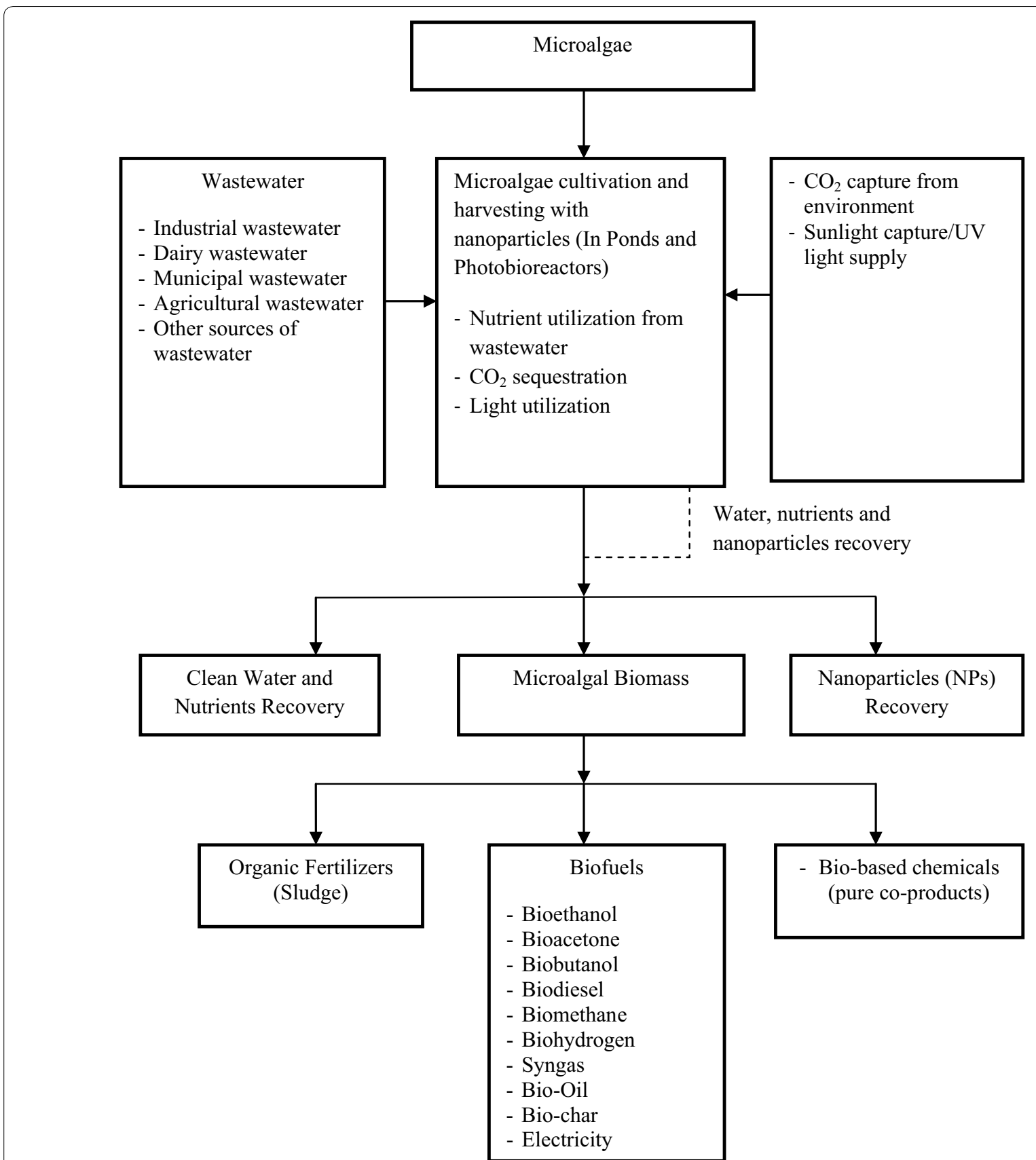

Fig. 2 Process flow diagram of carbon capture, water treatment and biofuels production from microalgae incorporated with nano-particles [18, 25, 49-54]

were doped with microalgal biofuel (e.g., microalgae oil, biodiesel, bioethanol, and others) with different doses (e.g., $25 \mathrm{ppm}, 50 \mathrm{ppm}, 100 \mathrm{ppm}$, and others) via ultrasonication processing by the presence of magnetic stirrer and implemented on compression ignition (CI), direct ignition (DI) engines without any engine modification. NPs are dispersed in a base fuel and smoothen potential agglomerate into nano-scale due to its' larger surface area and surface energy [58-61]. The ultra-sonication method was conducted with various parameters such as frequency (e.g., $20 \mathrm{kHz}, 40 \mathrm{kHz}$, and $45 \mathrm{kHz}$ ), power (e.g., $120 \mathrm{~W}$ and $220 \mathrm{~W}$ ), and time (30 min and $60 \mathrm{~min})[60,62,63]$. Cationic surfactants, e.g., tetra methyl ammonium hydroxide, cetyl trimethyl ammonium bromide, have been incorporated on the nano-particle surface for a negative-charge envelope formation 
Table 3 Possible biofuels from microalgae and conversion processes

\begin{tabular}{|c|c|c|c|}
\hline Biofuel & Conversion processes & $\begin{array}{l}\text { Some potential nano-additives for biofuel } \\
\text { yield enhancement }\end{array}$ & References \\
\hline $\begin{array}{l}\text { Bioethanol, biobu- } \\
\text { tanol, biomethanol, } \\
\text { bioaceton }\end{array}$ & $\begin{array}{l}\text { Simultaneous saccharification and fermentation } \\
\text { (SSF) } \\
\text { Separate hydrolysis and fermentation (SHF) } \\
\text { Simultaneous saccharification and co-fermentation } \\
\text { (SSCF) } \\
\text { Separate hydrolysis and co-fermentation (SHCF) } \\
\text { Dark fermentation } \\
\text { Photo fermentation } \\
\text { Anaerobic fermentation } \\
\text { Acetone-butanol-ethanol (ABE) fermentation } \\
\text { Consolidated bioprocessing }\end{array}$ & $\mathrm{Fe}_{2} \mathrm{O}_{3}, \mathrm{CeO}_{2}-\mathrm{CNT}$ and others & {$[42,49,85-89]$} \\
\hline Biodiesel & $\begin{array}{l}\text { Lipid hydrolysis and chemical, physical, enzymatic } \\
\text { transesterification } \\
\text { Interesterification } \\
\text { Acidolysis } \\
\text { Alcoholysis associated with glycerolysis } \\
\text { Folch method (use of chloroform-methanol) } \\
\text { Bligh and dyer method (use of chloroform-metha- } \\
\text { nol) } \\
\text { Modified method of the Folch/Bligh and dyer } \\
\text { methods (use of methyl-tert-butyl-ether) } \\
\text { Superior solvent extraction method (use of chlo- } \\
\text { roform) } \\
\text { Direct or in situ supercritical transesterification } \\
\text { Post-transesterification } \\
\text { Wet extraction method } \\
\text { Deep eutectic solvent (DES) method }\end{array}$ & $\begin{array}{l}\mathrm{ZrO}_{2}, \mathrm{TiO}_{2}, \mathrm{Al}_{2} \mathrm{O}_{3}, \mathrm{CeO}_{2}, \mathrm{SiO}_{2}, \mathrm{Fe}_{2} \mathrm{O}_{3}, \mathrm{CaO}-\mathrm{NPs} \text { and } \\
\text { others }\end{array}$ & {$[46,77,78,90-100]$} \\
\hline Syngas & $\begin{array}{l}\text { Gasification } \\
\text { Pyrolysis } \\
\text { Direct combustion } \\
\text { Bio-electrochemical fuel cells } \\
\text { Supercritical water gasification (SCWG) } \\
\text { Hydrothermal gasification }\end{array}$ & $\mathrm{TiO}_{2}, \mathrm{CeO}_{2}$ and others & {$[88,101-105]$} \\
\hline Bio-electricity & $\begin{array}{l}\text { Bio-electrochemical system contain anode, cath- } \\
\text { ode and electrode } \\
\text { Direct combustion }\end{array}$ & $\mathrm{Fe}_{2} \mathrm{O}_{3}, \mathrm{CeO}_{2}-\mathrm{CNT}, \mathrm{CaO}-\mathrm{NPs}$ and others & [106-108] \\
\hline Biomethane & $\begin{array}{l}\text { Anaerobic digestion } \\
\text { Catalytic hydrothermal gasification }\end{array}$ & $\begin{array}{l}\mathrm{SiO}_{2} \text {, nano-particles of platinum (Pt), nickel }(\mathrm{Ni}) \text {, } \\
\text { cobalt }(\mathrm{Co}) \text {, iron }(\mathrm{Fe}) \text { and others }\end{array}$ & {$[46,109-112]$} \\
\hline Bio-hydrogen & $\begin{array}{l}\text { Solid-state anaerobic digestion } \\
\text { Biophotolysis } \\
\text { Photobiological hydrogen production } \\
\text { Dark fermentation } \\
\text { Photo fermentation } \\
\text { Solid-state fermentation } \\
\text { Suspended fermentation }\end{array}$ & $\mathrm{TiO}_{2}, \mathrm{CeO}_{2}$ and others & [113-118] \\
\hline Bio-oil and bio-char & $\begin{array}{l}\text { Hydrothermal (thermochemical) liquefaction } \\
\text { Pyrolysis } \\
\text { Expeller press } \\
\text { Bead beating } \\
\text { Ultrasound assisted extraction method } \\
\text { Microwave extraction method } \\
\text { Electroporation/electropermeabilization } \\
\text { Slow pyrolysis } \\
\text { Fast pyrolysis } \\
\text { Torrefaction } \\
\text { Hydrothermal carbonization } \\
\text { Hydrothermal liquefaction } \\
\text { lon exchange } \\
\text { Wet imprgenation } \\
\text { Catalytic hydropyrolysis } \\
\text { Hydrogenation } \\
\text { Hydrodeoxygenation }\end{array}$ & $\mathrm{CeO}_{2}-\mathrm{CNT}, \mathrm{SiO}_{2}-\mathrm{MgO}$ nanohybrids and others & {$[46,90,119-127]$} \\
\hline
\end{tabular}


Table 4 Applications of different dosages of nano-particles on biofuels and combinations of biofuel nano-particle blend and application output

\begin{tabular}{|c|c|c|c|c|c|c|}
\hline $\begin{array}{l}\text { Microalgal } \\
\text { and other } \\
\text { biofuel }\end{array}$ & $\begin{array}{l}\text { Sources for biofuel } \\
\text { extraction }\end{array}$ & $\begin{array}{l}\text { Nano-particles } \\
\text { (NPs) }\end{array}$ & Dosage & $\begin{array}{l}\text { Combinations } \\
\text { of biofuel and nano- } \\
\text { particle blends }\end{array}$ & Application output & References \\
\hline Biodiesel & Caulerpa racemosa & $\mathrm{ZrO}_{2}$ & $\begin{array}{l}50 \mathrm{ppm} \\
100 \mathrm{ppm}\end{array}$ & $\begin{array}{l}\text { B2050 ppm } \\
\text { B20100 ppm }\end{array}$ & $\begin{array}{l}\text { Reduction of hydrocarbon }(\mathrm{HC}) \text {, } \\
\text { carbon-mono oxide }(\mathrm{CO}) \\
\text { Nitrogen oxides }\left(\mathrm{NO}_{x}\right) \text { emission } \\
\text { increase }\end{array}$ & [59] \\
\hline Biodiesel & Madhuca longifolia & $\mathrm{TiO}_{2}$ & $\begin{array}{l}100 \mathrm{ppm} \\
200 \mathrm{ppm}\end{array}$ & $\begin{array}{l}\text { BD100T100 ppm } \\
\text { BD100T200 ppm }\end{array}$ & $\begin{array}{l}\text { Reduction of } 5.8 \% \text { unburned } \mathrm{HC} \text {, } \\
9.3 \% \mathrm{CO}, 2.7 \% \text { smoke and } 6.6 \% \\
\mathrm{NO}_{x} \text { emission }\end{array}$ & {$[128]$} \\
\hline $\begin{array}{l}\text { Biodiesel } \\
\text { blended with } \\
\text { diesel }\end{array}$ & Jatropha curcas & $\begin{array}{l}\mathrm{Al}_{2} \mathrm{O}_{3} \\
\mathrm{CeO}_{2}\end{array}$ & $\begin{array}{l}30 \mathrm{ppm} \\
30 \mathrm{ppm}\end{array}$ & B20A30C30 ppm & $\begin{array}{l}12 \% \text { improved brake thermal } \\
\text { efficiency } \\
\text { Reduction of } 30 \% \mathrm{NO}_{x}, 60 \% \mathrm{CO} \text {, } \\
44 \% \mathrm{HC} \text { and } 38 \% \text { smoke }\end{array}$ & {$[61]$} \\
\hline Biodiesel & Jatropha curcas & $\begin{array}{l}\mathrm{Al}_{2} \mathrm{O}_{3} \\
\mathrm{CeO}_{2}\end{array}$ & $\begin{array}{l}30 \mathrm{ppm} \\
30 \mathrm{ppm}\end{array}$ & B100A30C30 ppm & $\begin{array}{l}\text { Improved brake thermal effi- } \\
\text { ciency } \\
\text { Reduction of } \mathrm{NO}_{x^{\prime}} \mathrm{CO}, \mathrm{HC} \text { and } \\
\text { smoke }\end{array}$ & {$[61]$} \\
\hline Biodiesel & Botryococcus braunii & $\begin{array}{l}\mathrm{TiO}_{2} \\
\mathrm{SiO}_{2}\end{array}$ & $\begin{array}{l}50 \mathrm{ppm} \\
100 \mathrm{ppm}\end{array}$ & $\begin{array}{l}\mathrm{B} 20 \mathrm{TiO}_{2} \mathrm{SiO}_{2} 50 \mathrm{ppm} \\
\mathrm{B}_{2} 0 \mathrm{TiO}_{2} \mathrm{SiO}_{2} 100 \mathrm{ppm}\end{array}$ & $\begin{array}{l}\text { Increased calorific value } \\
\text { Decrease in brake-specific fuel } \\
\text { consumption (BSFC) } \\
\text { Improved brake thermal effi- } \\
\text { ciency (BTE) } \\
\text { Reduction of ignition delay time } \\
\text { Improved brake thermal effi- } \\
\text { ciency } \\
\text { Improvement of combustion } \\
\text { characteristics } \\
\text { Minimum } \mathrm{CO}, \mathrm{HC} \\
\text { Maximum } \mathrm{NO}_{x^{\prime}} \mathrm{CO}_{2}\end{array}$ & {$[60]$} \\
\hline Biodiesel & Pongamia pinnata & $\mathrm{Rh}_{2} \mathrm{O}_{3}$ & $100 \mathrm{~nm}$ & $\mathrm{~B} 100 \mathrm{Rh}_{2} \mathrm{O}_{3}$ & $\begin{array}{l}\text { Reduces } \mathrm{CO}, 37 \% \mathrm{NO}_{x^{\prime}} 45 \% \\
\text { unburnt } \mathrm{HC} \\
\text { Improvement of thermal } \\
\text { efficiency }\end{array}$ & {$[58]$} \\
\hline Biodiesel & Glycine max & $\mathrm{CO}_{3} \mathrm{O}_{4}$ & $\begin{array}{l}100 \mathrm{mg} / \mathrm{l} \\
38-70 \mathrm{~nm}\end{array}$ & $\mathrm{~B} 100 \mathrm{CO}_{3} \mathrm{O}_{4}$ & $\begin{array}{l}\text { 1.03\% better engine perfor- } \\
\text { mance than usual biodiesel } \\
\text { combustion } \\
\text { Reduction of smoke and } 7.46 \% \\
\mathrm{NO}_{x} \text { emission }\end{array}$ & {$[56]$} \\
\hline Biodiesel & Glycine max & $\mathrm{Al}-\mathrm{Mg}$ & $\begin{array}{l}100 \mathrm{mg} / \mathrm{l} \\
38-70 \mathrm{~nm}\end{array}$ & B100Al-Mg & $\begin{array}{l}\text { Better engine performance than } \\
\text { usual biodiesel combustion } \\
\text { Reduction of smoke and } 16.33 \% \\
\mathrm{NO}_{x} \text { emission }\end{array}$ & {$[56]$} \\
\hline Biodiesel & Jatropha curcas & $\begin{array}{l}\mathrm{Al}_{2} \mathrm{O}_{3} \\
\mathrm{Al}_{2} \mathrm{O}_{3} \\
\text { Carbon nano-tube } \\
\quad(\mathrm{CNT}) \\
\mathrm{Al}_{2} \mathrm{O}_{3} \mathrm{CNT}\end{array}$ & $\begin{array}{l}25 \mathrm{ppm} \\
50 \mathrm{ppm}\end{array}$ & $\begin{array}{l}\mathrm{BAl}_{2} \mathrm{O}_{3} \mathrm{ppm} \\
\mathrm{BAI}_{2} \mathrm{O}_{3} \mathrm{ppm} \\
\mathrm{BCNT} 25 \mathrm{ppm} \\
\mathrm{BCNT50} \mathrm{ppm} \\
\mathrm{BAI}_{2} \mathrm{O}_{3} \mathrm{CNT} \\
25 \mathrm{ppm}\end{array}$ & $\begin{array}{l}\text { Considerable enhancement of } \\
\text { brake thermal efficiency } \\
\text { Marginal reduction of harmful } \\
\text { emissions } \\
\text { Improved heat transfer rate } \\
\text { Short ignition delay effect } \\
\text { Enhancement of heat conduc- } \\
\text { tion properties and surface } \\
\text { area/volume ratio }\end{array}$ & [129] \\
\hline Biodiesel & Azadirachta indica & $\mathrm{Ag}_{2} \mathrm{O}$ & $5 \mathrm{ppm}$ & $\begin{array}{l}\mathrm{B} 100 \mathrm{Ag}_{2} \mathrm{O} \\
5 \mathrm{ppm}\end{array}$ & $\begin{array}{l}\text { Decrease of } 12.22 \% \mathrm{CO}, 10.89 \% \\
\mathrm{HC}, 4.24 \% \mathrm{NO}_{x} \text { and } 6.61 \% \\
\text { smoke } \\
\text { Enhancement of brake thermal } \\
\text { efficiency with reduction in } \\
\text { brake-specific fuel consump- } \\
\text { tion }\end{array}$ & [63] \\
\hline
\end{tabular}


Table 4 (continued)

\begin{tabular}{|c|c|c|c|c|c|c|}
\hline $\begin{array}{l}\text { Microalgal } \\
\text { and other } \\
\text { biofuel }\end{array}$ & $\begin{array}{l}\text { Sources for biofuel } \\
\text { extraction }\end{array}$ & $\begin{array}{l}\text { Nano-particles } \\
\text { (NPs) }\end{array}$ & Dosage & $\begin{array}{l}\text { Combinations } \\
\text { of biofuel and nano- } \\
\text { particle blends }\end{array}$ & Application output & References \\
\hline Biodiesel & Azadirachta indica & $\mathrm{Ag}_{2} \mathrm{O}$ & 10 ppm & $\begin{array}{l}\mathrm{B} 100 \mathrm{Ag}_{2} \mathrm{O} \\
10 \mathrm{ppm}\end{array}$ & $\begin{array}{l}\text { Reduction of } 16.47 \% \mathrm{CO}, 14.21 \% \\
\mathrm{HC}, 6.66 \% \mathrm{NO}_{x} \text { and } 8.34 \% \\
\text { smoke } \\
\text { Significant improvement of } \\
\text { brake thermal efficiency with } \\
\text { reduction in brake-specific fuel } \\
\text { consumption }\end{array}$ & [63] \\
\hline Biodiesel & Jatropha curcas & $\mathrm{CO}_{3} \mathrm{O}_{4}$ & - & 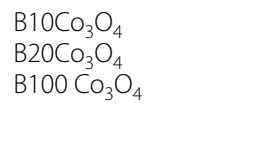 & $\begin{array}{l}\text { Reduction of the ignition delay } \\
\text { Improvement of combustion by } \\
\text { its'catalytic effect } \\
\text { Burning of the carbon deposits } \\
\text { Reduction of black smoke }\end{array}$ & {$[57]$} \\
\hline $\begin{array}{l}\text { Biodiesel- } \\
\text { bioethanol }\end{array}$ & Vegetable oil-alcohol & $\mathrm{Fe}_{2} \mathrm{O}_{3}$ & 150 ppm & $\mathrm{BB} \mathrm{Fe}_{2} \mathrm{O}_{3} 150 \mathrm{ppm}$ & $\begin{array}{l}1 \% \text { increase in thermal efficiency } \\
60 \% \text { reduction of emission char- } \\
\text { acteristics, reduction of } \mathrm{NO}_{x^{\prime}} \\
\mathrm{CO}, \mathrm{HC} \text { and smoke } \\
\text { Better mixing } \\
\text { Presence of secondary atomiza- } \\
\text { tion, disruption of primary } \\
\text { droplet } \\
\text { Complete combustion }\end{array}$ & {$[57]$} \\
\hline Biodiesel & Azadirachta indica & $\mathrm{CaCO}_{3}$ nano-fluids & $\begin{array}{l}3 \mathrm{mg} / \mathrm{l} \\
5 \mathrm{mg} / \mathrm{l}\end{array}$ & $\mathrm{B} 100 \mathrm{CaCO}_{3}$ & $\begin{array}{l}\text { Reduction of } 4.08 \% \text { specific fuel } \\
\text { consumption reduction } \\
3.9 \% \text { increase of brake thermal } \\
\text { efficiency } \\
8.57 \% \text { higher mechanical } \\
\text { efficiency } \\
\text { Reduction of } \mathrm{NO}_{x} \text { and } \mathrm{HC} \text { emis- } \\
\text { sion }\end{array}$ & [130] \\
\hline Biodiesel & Linum usitatissimum & $\mathrm{CuO}$ & $\begin{array}{l}80 \mathrm{ppm} \\
40 \mu \mathrm{mol} / \mathrm{L} \\
80 \mu \mathrm{mol} / \mathrm{L} \\
120 \mu \mathrm{mol} / \mathrm{L}\end{array}$ & B20CuO80 ppm & $\begin{array}{l}\text { Significant increase in thermal } \\
\text { efficiency } \\
3-4 \% \text { increase of brake thermal } \\
\text { efficiency } \\
25 \% \text { reduction of } \mathrm{CO} \\
\text { Reduction of } \mathrm{NO}_{x} \text { and } \mathrm{HC} \text { emis- } \\
\text { sion }\end{array}$ & {$[62]$} \\
\hline $\begin{array}{l}\text { Biodiesel-cas- } \\
\text { toroil-diesel- } \\
\text { bioethanol }\end{array}$ & $\begin{array}{l}\text { Vegetable oil-Ricinus } \\
\text { communis oil } \\
\text { Vegetable oil-alcohol }\end{array}$ & $\mathrm{CeO}_{2}-\mathrm{CNT}$ & $\begin{array}{l}25 \mathrm{ppm} \\
50 \mathrm{ppm} \\
100 \mathrm{ppm}\end{array}$ & - & $\begin{array}{l}\text { Reduction of } \mathrm{HC}, \mathrm{CO}, \mathrm{CO}_{2} \text {, smoke } \\
\text { and } \mathrm{NO}_{x} \\
\text { Increase of calorific value and } \\
\text { brake thermal efficiency }\end{array}$ & {$[84]$} \\
\hline Biodiesel & & $\mathrm{FeCl}_{3}$ & $20 \mu \mathrm{mol} / \mathrm{l}$ & $\mathrm{BFeCl}_{3} 25$ & $\begin{array}{l}\text { Reduction of } \mathrm{HC}, \mathrm{CO}, \mathrm{CO}_{2} \text {, smoke } \\
\text { and } \mathrm{NO}_{x} \\
\text { Increase of calorific value and } \\
\text { brake thermal efficiency }\end{array}$ & {$[84]$} \\
\hline
\end{tabular}

to resist NPs' sedimentation [56, 64]. After biofuel-NPs' doping, the NP-blended biofuel was preserved under the static condition to stabilize for fuel purpose [59]. Several potential NPs-microalgae-biofuel blends are tabulated in Table 4. The morphology and crystalline phases after NP-doping were analysed through a scanning electron microscope and X-ray diffraction, respectively [61]. Botryococcus braunii oil was doped with almost $50 \mathrm{~nm}$ sized titanium dioxide $\left(\mathrm{TiO}_{2}\right)$ and silicon dioxide $\left(\mathrm{SiO}_{2}\right)$ incorporated with biodiesel (B20) of different doses for enhanced fuel efficiency in CI engine [60]. Caulerpa racemosa green algae biodiesel (B20) was doped with $50 \mathrm{~nm}$ sized zirconium dioxide $\left(\mathrm{ZrO}_{2}\right)$ by the different doses for CI engine [59].

\section{Future applications of nano-additives for microalgae-biofuel}

Nano-additive application on microalgae-biofuel enhancement has been categorized into several stages from raw material production to end-product implications. The stages are:

(i) nano-additives for microalgae cultivation; 
Table 5 Harvesting efficiency of various microalgae species with the addition of nano-particles

\begin{tabular}{|c|c|c|c|}
\hline Microalgae species & Nano-particles & $\begin{array}{l}\text { Harvesting } \\
\text { efficiency (\%) }\end{array}$ & References \\
\hline Chlorella ellipsoidea & Modified Chu 13, doses 380 mg/g & 90 & [22] \\
\hline Chlorella ellipsoidea & $\mathrm{Fe}_{3} \mathrm{O}_{4}$ nano-particles functionally coated with polyethylenimine (PEI) & 97 & {$[22]$} \\
\hline Chlorella ellipsoidea & Iron oxide and cationic polyacrylamide (CPAM), doses 120 mg/l & $>95$ & [131] \\
\hline Botryococcus braunii & Modified Chu 13, doses $20 \mathrm{mg} / \mathrm{g}$ & 100 & [22] \\
\hline Botryococcus braunii & Iron oxide and CPAM, doses 15 mg/l & $>95$ & [131] \\
\hline Marine Nannochloropsis sp. & Magnetic $\mathrm{Fe}_{3} \mathrm{O}_{4}$ nano-particles, doses 99 mg/g & 95 & [22] \\
\hline Chlorella sp. & $\begin{array}{l}\text { Surface-functionalized iron-oxide nano-particles (SF-IONPS) with PDA (poly } \\
\text { dimethylammonium chloride) }\end{array}$ & 99 & [22] \\
\hline Chlorella sp. & Chitosan/magnetic nano-particles (CS-MNPs) & 97 & [132] \\
\hline Chlorella sp. KR-1 & Naked $\mathrm{Fe}_{3} \mathrm{O}_{4}$ magnetic particles & 90 & {$[22]$} \\
\hline
\end{tabular}

(ii) nano-additives for microalgae biomass conversion to biofuels;

(iii) nano-additives for microalgae-biofuel applications.

\section{Nano-additives for microalgae cultivation}

Improvement of the microalgae biomass productivity with the minimum area requirement is considered as the main purpose of nano-additive application in the microalgae culture. Nano-technology is being applied for enzyme immobilization, since nano-structures broaden the immobilization surface area causing high loading power of enzymes and stability of immobilized enzymes. Enzyme immobilization can be performed in different approaches such as electrospun nanofibers, covalently attached enzymes into nano-fibres, and enzyme aggregate coatings on nanofibers. The enzyme immobilization was investigated on various carbon nano-particles, e.g., graphene oxide (GO), multi-walled carbon nano-tubes (MWNTs), oxidized-MWNTs (O-MWNTs), and fullerene (C60). Among these nano-structures, O-MWNTs yielded the highest, and C60 yielded the lowest [21, 22]. Nano-particles' (NPs') application was implemented on several microalgae species harvesting and yielded outstanding in each phase of the application. Application of nano-particles on microalgae harvesting claimed 20-30\% microalgae production cost in large-scale application [22]. Table 5 presents the harvesting efficiency of several microalgae species cultivated with various nano-particles. Nano-particles also boosted the light conversion efficiency in photobioreactor (PBR) during the microalgae culture period. It is also worth mentioning that PBR is run by artificial light sources consuming additional energy and cost. However, during biomass growth, light sources do not reach in culture broth inadequately due to self-shading and biofilm formation on the PBR surface.
To achieve desired illumination properties and photoconversion efficiency in the PBR, various light-emitting diodes (LEDs) equipped with nano-materials fabrication are being implemented recently. Gallium aluminum arsenide (GAA)-fabricated LEDs have been experimented on laboratory scale algae culture so far. It was evident that the application of optical fibres in algal culture saves much energy, additional light cost, and increase efficiency [18]. Another latest development of nano-particle, integration of metallic nano-particles (MNPs) with localized surface plasmon resonance (LSPRs) amplifies the light scattering at certain wavelength [65]. An experimental study revealed that silver nano-particles' (Ag-NPs') suspension in plasmonic mini-PBRs backscatter blue light strongly. The blue light increased the photosynthetic efficiency significantly for green microalgae, Chlamydomonas reinhardtii, and blue-green microalgae, Cyanothece 51142, and 30\% higher microalgae biomass have been obtained [48]. Nano-particles addition in microalgae cultivation can also improve the yield of the $\mathrm{CO}_{2}$ absorption from the atmosphere and $\mathrm{CO}_{2}$ sequestration that can boost the biomass growth. For instance, nano-bubbles in microalgae culture remained stable for a longer time. Nano-bubbles also floated algae biomass into the culture, ensured high mass transfer efficiency, and improved biomass density by sufficient accumulation of $\mathrm{CO}_{2}, \mathrm{O}_{2}$ stripping, and minor buoyancy. Moreover, nano-bubbles suspended the biomass around airlift-loop bioreactor (ALB) and required less energy than microbubbles. Uniform nonporous membrane of ALB was also capable of producing $100 \mathrm{~nm}$ sized bubbles for this purpose $[18,66,67]$. The previous studies also delineated that nano-additives played a significant role in flocculation and separation process before biofuel production besides microalgae harvesting [22]. 


\section{Nano-additives for microalgae biomass conversion to biofuels}

Among microalgae biofuel, biodiesel has been appeared as the most popular and commercial biofuel in the mobile fuel market. For the case of biodiesel production, applications of acidic and basic nano-catalyst spheres can substitute the chemical compounds such as sodium methoxide by reacting with the free fatty acids and oils. Additional advantages of these nano-catalysts are recyclability and positive economical impact. Moreover, reactions can take place with low temperature and pressure as well as this approach reduces the contaminant release to the environment borne by sodium methoxide [6]. An industrial biodiesel study demonstrated that commercial CaO-NPs presented 91\% biodiesel conversion efficiency during scaled-up catalytic transesterification [18]. Experimental study of microalgae cultivation with spherical nano-particles composed with sand (silica) and calcium compounds revealed that microalgae cellular growth increased drastically without harming harvesting as well as biofuel production from vegetable oil. The best way to address this issue was described as one of the major driving factors for commercial biofuel, biofuel production cost dropped effectively $[6-8,68]$. The experimental study mentioned that mesoporous silica nano-catalyst, Ti-loaded SBA-15 presented ten times higher free fatty acids (FFA) and water tolerance level than any other catalysts for biodiesel production from vegetable oil as well as this nano-catalyst performed three times better than other effective nano-catalysts titanium silicalite-1 (TS-1) and titanium dioxide silicate $\left(\mathrm{TiO}_{2}-\mathrm{S}\right)$ [69].

Moreover, Ti-loaded Santa Barbara Amorphous-15 (SBA-15) nano-catalyst application reduced the chemical (alkaline catalyst, $\mathrm{NaOH}$ ) cost of transesterification process for biodiesel production by recycling the nanocatalyst as well as this process is more environmentfriendly $[6,69]$. On the other hand, sulfate incorporated Ti-SBA-15 also performed as biocatalyst to convert vegetable oil to $100 \%$ esterified bio-lubricant. In consequences, this nano-particle can be expected to produce bio-lubricant from bio-oil of microalgae [70]. Other study showed that Niobia $\left(\mathrm{N}_{2} \mathrm{O}_{5}\right)$ incorporated with SBA15 application on biodiesel production from biomass through esterification presented a significant scenario for microalgae-biodiesel yield [71]. Another study delineated that the enzyme extracted from Pseudomonas cepacia conjuncts with the nano-particles such as polyacrylonitrile (PAN) nanofibre, $\mathrm{Fe}_{3} \mathrm{O}_{4}$, and nanoporous gold; silica nano-particles with lipase enzyme from Rhizopus miehei; ferric silica and magnetic nano-particles with lipase from Burkholderia sp., polyacrylonitrile nano-fibre bound with lipase from Thermomyces lanuginosa has performed very effectively to produce biodiesel from various bio-oil by the transesterification process [7]. Furthermore, nanomagnetic biocatalyst of $\mathrm{KF} / \mathrm{CaO}-\mathrm{Fe}_{3} \mathrm{O}_{4}, \mathrm{Li}$ (lithium)doped $\mathrm{CaO}, \mathrm{Fe}_{2} \mathrm{O}_{3}-\mathrm{CaO}$, sulfate $\left(\mathrm{SO}_{4}{ }^{-}\right)$incorporated $\mathrm{Zi}$ (zirconium), sodium titanate and carbon-based nanotubes and nano-particles reached up to $95 \%$ or above biodiesel yield from diverse types of biomass and biodegradable waste [7, 72]. Besides enhancement of biodieselyield efficiency, a type of NP, zeolite (an alumina silicate mineral), has been used as commercial absorbent during the transesterification process. Zeolites absorbed the undesirable moisture content (4-6\%) and produced pure glycerine as co-product besides biodiesel. Mesoporous nano-particles also presented a vital capability for continuous microalgal-biofuel generation from biomass without cell lysis. Zeolites also removed lipids from the microalgae cell membrane [18, 73]. Table 6 presented the applications of nano-additives for biodiesel-yield enhancements during microalgae to biofuel conversion, suitable conversion processes, and efficiencies.

Nano-particles were efficiently capable to perform as immobilizing beds for valuable enzymes due to their large surface area-to-volume ratio. This capability of NPs broke down the long chains of complex sugar of microalgae,

Table 6 Applications of nano-additives for biodiesel-yield enhancements during microalgae to biofuel conversion, suitable conversion processes, and efficiencies

\begin{tabular}{|c|c|c|c|}
\hline Nano-additives & Conversion processes & Conversion efficiency & References \\
\hline Calcium oxide nano-particles' blends (CaO-NPs) & Catalytic transesterification & $91 \%$ & {$[18]$} \\
\hline Mesoporous silica nano-catalyst, Ti-loaded SBA-15 & Transesterification & $\begin{array}{l}10 \text { times higher yield than other catalysts } \\
3 \text { times higher than other effective nano- } \\
\text { catalysts } \mathrm{TS}-1 \text { and } \mathrm{TiO}_{2}-\mathrm{S}\end{array}$ & {$[6,69]$} \\
\hline Niobia $\left(\mathrm{N}_{2} \mathrm{O}_{5}\right)$ incorporated with SBA-15 & Esterification & Significant increase of biodiesel yield & {$[71]$} \\
\hline $\begin{array}{l}\text { PAN nanofibre, } \mathrm{Fe}_{3} \mathrm{O}_{4} \text { and nanoporous gold incorpora- } \\
\text { tion, silica nano-particles, ferric silica and magnetic } \\
\text { nano-particles incorporation, polyacrylonitrile nano } \\
\text { fibre transesterification process }\end{array}$ & Transesterification & Effective rise in biodiesel productivity & {$[7]$} \\
\hline $\begin{array}{l}\mathrm{KF} / \mathrm{CaO}-\mathrm{Fe}_{3} \mathrm{O}_{4} \text {, } \mathrm{Li} \text { (lithium)-doped } \mathrm{CaO}, \mathrm{Fe}_{2} \mathrm{O}_{3}-\mathrm{CaO} \text {, sul- } \\
\text { fate }\left(\mathrm{SO}_{4}^{-}\right) \text {incorporated } \mathrm{Zi} \text { (zirconium), sodium titan- } \\
\text { ate and carbon-based nano-tubes and nano-particles }\end{array}$ & Transesterification & $\geq 95 \%$ & {$[7,72]$} \\
\hline
\end{tabular}


converted it to simple sugar, and consequently turned into bioethanol via the fermentation process. Due to the large surface area, the interaction between the surface of the nano-particles and fuel surrounded by them achieved adequate stability to overcome density variations. Nanoparticles prepared by carbon nano-tubes doped with iron-oxide nano-particles presented excellent biocatalytic efficiency in a bioreactor, recyclable option enzyme applications, less capital cost as well as better enzyme loading for this purpose $[6,7,74]$. A catalytic study mentioned that mesoporous niobium oxide $\left(\mathrm{N}_{2} \mathrm{O}_{5}\right)$ application on complex sugar (sucrose) possessed both Lewis acid (LA) and Bronsted acid (BA) sites to convert fructose to 5-hydroxymethylfurfural (HMF) with the highest yield so far. The synergistic catalytic effect from a large amount of both LA and BA acid site quantities and surface areas played a positive impact on the reaction rate with a few times faster conversions [75]. Functionalised multiwall carbon-nano-tube (MWCNT) immobilization presented more than 55\% initial activity of microalgal hydrolysis for Candida Antarctica. Nano-catalysts such as cobalt-molybdenum fabricated with $\mathrm{Si} / \mathrm{Al}$ have been experimented on Botryococcus braunii and presented stable hydrocarbons. Another nano-catalyst, mobil composition of matter No. 41 (MCM-41), mesoporous material effectively reduced oxygenated fractions of bio-oil through catalytic pyrolysis [18].

Nano-catalysts can synthesize biomethane produced from microalgae from wastewater into pure hydrogen and carbon content. In a further step, this methane can produce biogas through anaerobic digestion. Biogas could be used as raw material of bio-fuelled electricity generation further. The elemental carbon can also be utilized as pure nano-graphite for the applications on batteries, aerospace, automobiles, and others [6]. The latest development conducted by quantum sphere on marine microalgae species evinced biogasification from wet microalgae biomass by metal nano-catalysts [18]. Besides that, nano-particles such as $\mathrm{TiO}_{2}, \mathrm{CeO}_{2}$ were manifested to improve $10-11 \%$ of the biogas yield from wastewater treatment. Therefore, these nano-particles can be projected further for the biomethane production from microalgae grown in wastewater [7]. Apart from that, nano-substances with $\mathrm{SiO}_{2}$, nano-particles of platinum $(\mathrm{Pt})$, nickel $(\mathrm{Ni})$, cobalt $(\mathrm{Co})$, and iron $(\mathrm{Fe})$ can increase methane production from biomass up to $70 \%$. Nano-fly ash and nano-bottom ash were proved to increase biomethane yield up to 3.5 times more. Nanometal oxides, e.g., $\mathrm{MgO}, \mathrm{CaO}$, and $\mathrm{SrO}$, nano-materials such as silica, single-walled nano-tubes of carbon-based materials, nano-clay, and nano-zero valence metal applications in biodiesel, bio-hydrogen, and biomethane production from microalgae and other biomass presented outstanding yield. These nano-particles can be projected for large-scale microalgal-biofuel production in the future to obtain revolutionary yield $[7,8]$. In addition, nano-hybrid catalysts are being commercialized as emulsion stabilizers in industrial applications. For instance, quaternary ammonium salts have been documented as an emulsifying surfactant for separation, extraction, isolation, and purification of biofuels. Carbon nano-tubes with silica fusion, $\mathrm{SiO}_{2}-\mathrm{MgO}$ nanohybrids have been performed as stabilizers on bio-oil in water emulsion due to its inherent hydrophobicity and resulted in full conversion in different emulsion phases [18].

\section{Nano-additives for microalgae-biofuel applications}

Solid nano-particles, nano-fluids, or nano-droplets with biofuel and fossil fuel were proved to improve the fuel lubricity, cetane number, burning rate, chemical reaction, catalytic performance, fire/flash point, heat and mass transfer efficiency and water co-solvency as well as decrease delay period $[76,77]$. That resulted in more complete and cleaner combustion of microalgae biofuel mixed with fossil fuel in compression ignition (CI), spark ignition (SI), and direct ignition (DI) engines. In line with that, nano-technology applications showed the capability of amplifying microalgal-biofuel combustion efficiency and reduced soot, $\mathrm{NO}_{x}$, smoke, $\mathrm{HC}, \mathrm{CO}_{2}$, and $\mathrm{CO}$ emission to the environment up to $72 \%[6,76,78]$. Application of solid nano-additives such as alumina $\left(\mathrm{Al}_{2} \mathrm{O}_{3}\right)$, CERIA, carbon nano-tubes (CNT), $\mathrm{Co}_{3} \mathrm{O}_{4}, \mathrm{ZrO}_{2}, \mathrm{La}_{2} \mathrm{O}_{3}$, $\mathrm{CeO}_{2}, \mathrm{SiO}_{2}, \mathrm{Ni}_{2} \mathrm{O}, \mathrm{TiO}_{2}, \mathrm{ZnO}, \mathrm{Fe}_{2} \mathrm{O}_{3}, \mathrm{CuO}, \mathrm{Ce}_{x} \mathrm{Zr}_{(1-x)} \mathrm{O}_{2}$, and amide-doped MWCNTs- $\mathrm{CeO}_{2}$ boosted the engine power, torque, and brake thermal performance of biodiesel (extracted from microalgae and other biomass) in $\mathrm{CI}$ and DI engines up to $11 \%[59,76,79,80]$. The experimental study of nano-particles on DI engines demonstrated that nano-particles blended with biodiesel as well as diesel-biodiesel mixture performed outstanding. The effectiveness was higher compared to usual catalysts $[61,81]$. Another study presented that nano-particles of $\mathrm{CeO}_{2}$ incorporated with an emulsion of biofuel with solgel combustion technology performed excellent monocylinder 4 stroke direct CI and DI engines without any hardware modification. Nano-particles addition with biofuels escalated the fuel calorific value, fastened evaporation rate, improved brake-specific fuel consumptions and thermal efficiency, reduced greenhouse gases (GHGs) such as $\mathrm{CO}, \mathrm{NO}_{x}$, and smoke, and unburned HCs. Chemical reactions between $\mathrm{CeO}_{2}$ and GHGs gases are presented in Rc. 2, Rc. 3, and Rc. 4 [82]:

$$
(2 y+x) \mathrm{CeO}_{2}+\mathrm{H}_{x} \mathrm{C}_{y} \rightarrow\left[\frac{2 y+x}{2}\right] \mathrm{Ce}_{2} \mathrm{O}_{3}+\frac{x}{2} \mathrm{H}_{2} \mathrm{O}+\frac{y}{2} \mathrm{CO}_{2}
$$




$$
\begin{aligned}
& 2 \mathrm{CeO}_{2}+\mathrm{CO} \rightarrow \mathrm{Ce}_{2} \mathrm{O}_{3}+\mathrm{CO}_{2} \\
& \mathrm{Ce}_{2} \mathrm{O}_{3}+\mathrm{NO} \rightarrow 2 \mathrm{CeO}_{2}+\frac{1}{2} \mathrm{~N}_{2} .
\end{aligned}
$$

In contrast, liquid nano-additive, nano-Al-droplet application (nano-suspension) on biofuel mixture has been manifested more efficient than even micro-suspension. Liquid nano-additives also presented outstanding performance by achieving better suspension than $n$-decane-based fuels. Nano-Al suspension with ethanol was strong enough for a longer period than other particles, because ethanol tended to form a gel around the nano-particles due to higher viscosity [74]. Nano-droplets coated a monolayer on the mechanical parts of the engine touched with liquid fuel and improved fuel efficiency [18]. In addition, NPs such as nano- $\mathrm{Al}, \mathrm{Al}_{2} \mathrm{O}_{3}$, $\mathrm{CuO}, \mathrm{MgO}, \mathrm{MnO}$, and $\mathrm{ZnO}$ incorporated with waterdiesel-biodiesel (E10) emulsion and bioethanol performed remarkably. Among these NPs, $\mathrm{Al}_{2} \mathrm{O}_{3}$ performed the best because of mandate disabling, consistent torque boosting, higher heat of combustion, super-high DTG $_{\text {max }}$ value, tiniest size of water droplets, the minimum value of brake-specific fuel consumption, and lowest values of Soot, $\mathrm{NO}_{x}, \mathrm{CO}$, and $\mathrm{HC}[19,83]$.

\section{Challenges and future prospects}

Although nano-additive applications played significant role in microalgae cultivation, harvesting, conversion to biofuel and biofuel applications to enhance the efficiency, yet some challenges remained before the implementation of nano-additives for the mercantile approach. Most of the nano-additives from experimental research were not well-characterized in terms of particle size, shape, and size distribution as well as clustering [84]. Before large-scale application, well characterization of nanoparticles and nano-fluids must be studied comprehensively. Appropriate nano-additive selection, preparation methods, and time for the selected application should be emphasized for optimum productivity. The effect of nano-catalyst implementation for microalgae-biofuel combustion quality, engine performance, and gas emission should be well studied and well-understood before implementation. In line with that, the availability of appropriate nano-additives with large amount might be a challenge for mass application though for laboratory scale, nano-additives are adequately available. Another constraint is cost-effectiveness of nano-catalysts for an industrial application which may hinder the commercial perspective, since many nano-catalysts are quite expensive.

Along with the potential microalgae determination and biofuel generation, integration of a plant design of value-added co-products will be the predominant advantage of the overall project with the economical aspect. This review encouraged biofuel research and development (R\&D) sector worldwide to convert their unused, abandoned and wastewater sources, wet, and barren lands into microalgae farm as an eminent source of biofuel production. However, it should be highlighted that based on the existing research experiments, microalgae fuel production still stands at initial stage due to downward economic profile worldwide. Nano-additive applications on microalgal biofuel are yet confined into laboratory and pilot scale which can be counted as a significant limitation. Hence, it is strongly recommended to figure out large-scale process development with nanoadditive applications for enhancement of microalgal growth, biofuel transformation processes, and fuel utilization in CI and DI engines. Nano-additive applications at different stages from microalgae culture to end-product utilization have a strong possibility to gain economical feasibility. Therefore, the detailed techno-economic analysis must be commanded to determine whether NP applications on microalgae biofuel are economically favorable or not, since economical issue is one of the most effective factors behind large-scale plant setup. Besides, these applications also have positive impact on the environment with value-added co-product generation into near further. Since the nano-additive utilization manifested itself environment-friendly, still a comprehensive life cycle assessment should be conducted to present the environmental positivities transparently. Besides all these factors, public safety, impact on flora and fauna, and the possibility of bio-hazards are also needed to be analysed extensively before commercialization.

\section{Conclusions}

Microalgae utilization for biofuel production is undoubtedly desirable all over the world. Though this approach is energy-efficient and environment-friendly, experts are still looking for an innovation that can boost the microalgae-biofuel yield from primary stage to end product as well as shift the whole process towards a cost-effective fuel solution. Hence, this review was emphasized on the synergistic effect of nano-additive-enhanced microalgal biofuel for mercantile approach and fuel-yield extension. Application of various forms of nano-additives in different phases on microalgae growth to biofuel demonstrated an excellent outcome that may project revolutionary improvement of commercial microalgae biofuel. However, the sustainability analysis of stepwise production rounds for microalgae biofuel still presented a bare need of further research and innovative concepts. These concepts may determine the most appropriate nanoadditive for the desired type of biofuel in the context of 
economical aspect. Since nano-additive application on microalgae is quite new research concept, policy making and implementation of nano-additives will remain as the most vital issues for commercial output especially in developing countries. Therefore, managerial insights are needed to be emphasized further on proper policy, socio-economic impact, advantages and limitations for the overall system to attract the government and nongovernment fuel industries.

\section{Highlights}

- Enhancement of microalgae cultivation and harvesting by nano-bubbles and nano-particles application.

- Identification of suitable microalgae species, possible biofuels from microalgae, latest conversion technologies, processes, and required equipments.

- Excellent microalgal-biofuel yield by nano-droplet and nano-additives.

- Complete and cleaner combustion in fuel engines by nano-emulsion and nano-stabilizers.
Availability of data and materials

Not applicable.

\section{Ethics approval and consent to participate}

The facts and views in the manuscript are ours and we are totally responsible for authenticity, validity, and originality. We also declare that manuscripts are our original work and we have not copied from anywhere else. There is no plagiarism in our manuscripts.

\section{Consent for publication}

We undertake and agree that the manuscripts submitted to your journal have not been published elsewhere and have not been simultaneously submitted to other journals.

\section{Competing interests}

The authors declare that they have no competing interests. The founding sponsors had no role in the design of the study; in the collection, analyses, or interpretation of data; in the writing of the manuscript, and in the decision to publish the results.

\section{Author details}

${ }^{1}$ Department of Civil and Infrastructure Engineering, School of Engineering, RMIT University, Melbourne, VIC 3001, Australia. ${ }^{2}$ School of Information, Systems and Modeling, Faculty of Engineering and Information Technology, University of Technology Sydney, Sydney, NSW 2007, Australia. ${ }^{3}$ Research Centre for Nano Materials and Energy Technology (RCNMET), School of Science and Technology, Sunway University, No. 5, Jalan University, 47500 Bandar Sunway, Petaling Jaya, Malaysia. ${ }^{4}$ Department of Engineering, Lancaster University, Lancaster LA1 4YW, UK.

Received: 30 January 2019 Accepted: 10 May 2019

Published online: 20 May 2019

\section{References}

1. Hossain N, Mahlia TMI, Zaini J, Saidur R. Techno-economics and sensitivity analysis of microalgae as commercial feedstock for bioethanol production. In: Environmental progress and sustainable energy. New Jersey: John Wiley \& Sons; 2019. p. 1-14.

2. Silitonga AS, Mahlia TMI, Ong HC, Riayatsyah TMI, Kusumo F, Ibrahim H, et al. A comparative study of biodiesel production methods for Reutealis trisperma biodiesel. Energ Source Part A. 2017;39:2006-14.

3. labal M, Khan FU. Hybrid vibration and wind energy harvesting using combined piezoelectric and electromagnetic conversion for bridge health monitoring applications. Energy Convers Manag. 2018;172:611-8

4. Hossain N, Jalil R. Sugar and bioethanol production from oil palm trunk (OPT). Asia Pac J Energ Environ. 2015;2:89-92.

5. Hossain N, Zaini JH, Mahlia TMI. A review of bioethanol production from plant-based waste biomass by yeast fermentation. Int J Technol. 2017:8:5-18.

6. Trindade SC. Nanotech biofuels and fuel additives, biofuel's engineering process technology. In: Bernardes MADS, editor. biofuel's engineering process technology. New York: InTech; 2011.

7. Palaniappan K. An overview of applications of nanotechnology in biofuel production. World Appl Sci J. 2017:35:1305-11.

8. Nizami A, Rehan M. Towards nanotechnology-based biofuel industry. Biofuel Res J. 2018;18:798-9.

9. Laurens LML, Chen-Glasser M, McMillan JD. A perspective on renewable bioenergy from photosynthetic algae as feedstock for biofuels and bioproducts. Algal Res. 2017;24:261-4.

10. Collotta M, Champagne P, Mabee W, Tomasoni G. Wastewater and waste $\mathrm{CO}_{2}$ for sustainable biofuels from microalgae. Algal Res. 2018;29:12-21.

11. Xu H, Lee U, Coleman AM, Wigmosta MS, Wang M. Assessment of algal biofuel resource potential in the United States with consideration of regional water stress. Algal Res. 2019;37:30-9.

12. Hossain N, Jalil R. Analyses of bio-energy properties from Malaysian local plants: sentang and sesendok. Asia Pac J Energy Environ. 2015:2:141-4. 
13. Goh BHH, Ong HC, Cheah MY, Chen W-H, Yu KL, Mahlia TMI. Sustainability of direct biodiesel synthesis from microalgae biomass: a critical review. Renew Sust Energy Rev. 2019;107:59-74.

14. Hossain N, Zaini J, Mahlia TMI. Experimental investigation of energy properties for Stigonematales sp. microalgae as potential biofuel feedstock. Int J Sustain Eng. 2019;12:123-30.

15. Gumba RE, Saallah S, Misson M, Ongkudon CM, Anton A. Green biodiesel production: a review on feedstock, catalyst, monolithic reactor, and supercritical fluid technology. Biofuel Res J. 2016;3:431-47.

16. Cheng JJ, Timilsina GR. Status and barriers of advanced biofuel technologies: a review. Renew Energy. 2011;36:3541-9.

17. Schenk PM, Thomas-Hall SR, Stephens E, Marx UC, Mussgnug JH, Posten C, et al. Second generation biofuels: high-efficiency microalgae for biodiesel production. Bioenergy Res. 2008;1:20-43.

18. Pattarkine MV, Pattarkine VM. Nanotechnology for algal biofuels. In: Gordon R, Seckbach J, editors. The science of algal fuels. Berlin: Springer; 2012. p. 149-60

19. Hasannuddin AK, Yahya WJ, Sarah S, Ithnin AM, Syahrullail S, Sidik NAC, et al. Nano-additives incorporated water in diesel emulsion fuel: fuel properties, performance and emission characteristics assessment. Energy Convers Manag. 2018;169:291-314.

20. Karthikeyan S, Prathima A. Microalgae biofuel with $\mathrm{CeO}_{2}$ nano additives as an eco-friendly fuel for $\mathrm{Cl}$ engine. Energy Source Part A. 2017;39:1332-8

21. Kim J, Jia H, Wang P. Challenges in biocatalysis for enzyme-based biofuel cells. Biotechnol Adv. 2006;24:296-308.

22. Safarik I, Prochazkova G, Pospiskova K, Branyik T. Magnetically modified microalgae and their applications. Crit Rev Biotechnol. 2016;36:931-41.

23. Rahman KM, Melville L, Huq SMI, Khoda SK. Understanding bioenergy production and optimisation at the nanoscale-a review. J Exp Nanosci. 2016:11:762-75.

24. Becker W. Microalgae for human and animal nutrition. In: Richmond A, editor. Handbook of microalgal culture: biotechnology and applied phycology. New York: Blackwell Publishing Ltd: Academic; 2003. p. 312-51.

25. Razzak SA, Hossain MM, Lucky RA, Bassi AS, Lasa HD. Integrated $\mathrm{CO}_{2}$ capture, wastewater treatment and biofuel production by microalgae culturing — a review. Renew Sust Energ Rev. 2013;27:622-53.

26. Hu Q, Sommerfeld M, Jarvis E, Ghirardi M, Posewitz M, Seibert M, et al. Microalgal triacylglycerols as feedstocks for biofuel production: perspectives and advances. Plant J. 2008;54:621-39.

27. Byreddy AR, Gupta A, Barrow CJ, Puri M. Comparison of cell disruption methods for improving lipid extraction from thraustochytrid strains. Mar Drugs. 2015;13:5111-27.

28. Norhasyima RS, Mahlia TMI. Advances in $\mathrm{CO}_{2}$ utilization technology: a patent landscape review. J CO2 Util. 2018;26:323-35.

29. Saïdane-Bchir F, El Falleh A, Ghabbarou E, Hamdi M. 3rd generation bioethanol production from microalgae isolated from slaughterhouse wastewater. Waste Biomass Valori. 2016;7:1041-6.

30. Sarkar B, Chakrabarti PP, Vijaykumar A, Kale V. Wastewater treatment in dairy industries_-possibility of reuse. Desalination. 2006:195:141-52.

31. Harun R, Danquah MK. Influence of acid pre-treatment on microalgal biomass for bioethanol production. Process Biochem. 2011;46:304-9.

32. Pathak V, Singh DP, Kothari R, Chopra AK. Phycoremediation of textile wastewater by unicellular microalga Chlorella pyrenoidosa. Cell Mol Biol (Noisy-le-Grand, France). 2014;60:35-40.

33. Umamaheswari J, Shanthakumar S. Efficacy of microalgae for industrial wastewater treatment: a review on operating conditions, treatment efficiency and biomass productivity. Rev Environ Sci Biotechnol. 2016:15:265-84

34. Spolaore $P$, Joannis-Cassan C, Duran E, Isambert A. Commercial applications of microalgae. J Biosci Bioeng. 2006;101:87-96.

35. Li-Beisson Y, Peltier G. Third-generation biofuels: current and future research on microalgal lipid biotechnology. OCL. 2013:20:D606.

36. Andersen RA. Biology and systematics of heterokont and haptophyte algae. Am J Bot. 2004:91:1508-22.

37. Beetul K, Bibi SS, Taleb-Hossenkhan N, Bhagooli R, Puchooa D. An investigation of biodiesel production from microalgae found in Mauritian waters. Biofuel Res J. 2014;1:58-64.

38. Fasahati P, Liu JJ. Process simulation of bioethanol production from brown algae. 8th IFAC Symposium on Advanced Control of Chemical
Processes; July 10-13, 2012; The International Federation of Automatic Control. Singapore: Furama Riverfront; 2012. p. 2012.

39. Hanh V, Minh N. Bioethanol production from marine algae biomass: prospect and troubles. J Viet Environ. 2012;3:25-9.

40. Chen $\mathrm{CY}$, Zhao XQ, Yen HW, Ho SH, Cheng CL, Lee DJ, et al. Microalgae-based carbohydrates for biofuel production. Biochem Eng J. 2013;78:1-10.

41. Matos ÂP, Torres RCO, Morioka LRI, Moecke EHS, França KB, Sant'Anna ES. Growing Chlorella vulgaris in photobioreactor by continuous process using concentrated desalination: effect of dilution rate on biochemical composition. Int J Chem Eng. 2014;2014:1-6.

42. Özçimen D, Inan B. An overview of bioethanol production from algae. New York: Intech Open; 2015.

43. Energy from Algae. Products, market, processes \& strategies. Chennai: Clixoo Solutions Pvt Ltd.; 2013.

44. Singh S, Kate BN, Banerjee UC. Bioactive compounds from cyanobacteria and microalgae: an overview. Crit Rev Biotechnol. 2005;25:73-95.

45. Costard GS, Machado RR, Barbarino E, Martino RC, Lourenço SO. Chemical composition of five marine microalgae that occur on the Brazilian coast. Int J Fish Aquac. 2012;4:191-201.

46. Brennan L, Owende P. Biofuels from microalgae-a review of technologies for production, processing, and extractions of biofuels and co-products. Renew Sust Energ Rev. 2010;14:557-77.

47. Hossain N, Zaini J, Mahlia TMI, Azad AK. Elemental, morphological and thermal analysis of mixed microalgae species from drain water. Renew Energy. 2019;131:617-24.

48. Torkamani S, Wani SN, Tang YJ, Sureshkumar R. Plasmon-enhanced microalgal growth in mini photobioreactors. Appl Phys Lett. 2010;97:1-4.

49. Cheng H-H, Whang LM, Chan KC, Chung MC, Wu SH, Liu CP, et al. Biological butanol production from microalgae-based biodiesel residues by Clostridium acetobutylicum. Bioresour Technol. 2015;184:379-85.

50. Debowski M, Zielinski M, Krzemieniewski M. Microalgae-cultivation method. Pol J Nat Sci. 2012;27:151-64.

51. Mohanakrishna G, Sandipam S, Pant D. Bioprocesses for waste and wastewater remediation for sustainable energy. Bioremidiation and bioeconomy. Belgium: Academic; 2016. p. 537-65.

52. Posadas E, Bochon S, Coca M, García-González MC, García-Encina PA, Muñoz R. Microalgae-based agro-industrial wastewater treatment: a preliminary screening of biodegradability. J Appl Phycol. 2014;26:2335-45.

53. Rasouli Z, Valverde-Pérez B, D’Este M, De Francisci D, Angelidaki I. Nutrient recovery from industrial wastewater as single cell protein by a co-culture of green microalgae and methanotrophs. Biochem Eng J. 2018;134:129-35.

54. Cheah WY, Ling TC, Show PL, Juan JC, Chang J-S, Lee D-J. Cultivation in wastewaters for energy: a microalgae platform. Appl Energy. 2016;179:609-25.

55. Zhang TY, Hu HY, Wu YH, Zhuang LL, Xu XQ, Wang XX, et al. Promising solutions to solve the bottlenecks in the large-scale cultivation of microalgae for biomass/bioenergy production. Renew Sust Energy Rev. 2016;60:1602-14.

56. Ganesh D, Gowrishankar G, editors. Effect of nano-fuel additive on emission reduction in a biodiesel fuelled $\mathrm{Cl}$ engine. In: International conference on electrical and control engineering; 2011. p. 16-18.

57. Sabarish R, Mohankumar D, Prem MJK, Manavalan S. Experimental study of nano additive with biodiesel and its blends for diesel engine. Int J Pure Appl Math. 2018;118:967-79.

58. Manibharathi S, Annadurai B, Chandraprakash R. Experimental investigation of $\mathrm{Cl}$ engine performance by nano additive in biofuel. Int J Sci Eng Technol Res. 2014;3:3303-7.

59. Karthikeyan S, Prathima A. Analysis of emissions from use of an algae biofuel with nano- $\mathrm{ZrO}_{2}$. Energy Source Part A. 2017;39:473-9.

60. Karthikeyan S, Prathima A. Environmental effect of $\mathrm{Cl}$ engine using microalgae methyl ester with doped nano additives. Transp Res D Transp Environ. 2017:50:385-96.

61. Prabu A. Nanoparticles as additive in biodiesel on the working characteristics of a DI diesel engine. Ain Shams Eng J. 2018;9:2343-9.

62. Jayanthi P, Srinivasa RM. Effects of nanoparticles additives on performance and emissions characteristics of a DI diesel engine fuelled with biodiesel. Int J Adv Eng Technol. 2016;9:689-95. 
63. Devarajan Y, Munuswamy DB, Mahalingam A. Influence of nanoadditive on performance and emission characteristics of a diesel engine running on neat neem oil biodiesel. Environ Sci Pollut Res Int. 2018;25:26167-72.

64. Ranaware AA, Satpute ST. Correlation between effects of cerium oxide nanoparticles and ferrofluid on the performance and emission characteristics of a Cl engine. IOSR J Mech Civil Eng. 2002;2278:55-9.

65. Steele JM, Grady NK, Nordlander P, Halas NJ. Plasmon hybridization in complex nanostructures. In: Brongersma ML, Kik PG, editors. Surface plasmon nanophotonics. Dordrecht: Springer; 2007. p. 183-96.

66. Zimmerman WB, Hewakandamby BN, Tesař V, Bandulasena HCH, Omotowa OA. On the design and simulation of an airlift loop bioreactor with microbubble generation by fluidic oscillation. Food Bioprod Process. 2009;87:215-27.

67. Zimmerman WB, Tesař $V$, Bandulasena $H$. Towards energy efficient nanobubble generation with fluidic oscillation. Curr Opin Colloid Interface Sci. 2011;16:350-6.

68. Silitonga AS, Atabani AE, Mahlia TMI, Masjuki HH, Badruddin IA, Mekhilef S. A review on prospect of Jatropha curcas for biodiesel in Indonesia. Renew Sust Energy Rev. 2011:15:3733-56.

69. Chen S-Y, Mochizuki T, Abe Y, Toba M, Yoshimura Y. Ti-incorporated SBA15 mesoporous silica as an efficient and robust Lewis solid acid catalyst for the production of high-quality biodiesel fuels. Appl Catal B Environ. 2014:148-149:344-56.

70. Sharma RV, Dalai AK. Synthesis of bio-lubricant from epoxy canola oil using sulfated Ti-SBA-15 catalyst. Appl Catal B Environ. 2013:142-143:604-14

71. Silva Â, Wilson K, Lee AF, dos Santos VC, Cons Bacilla AC, Mantovani KM, et al. $\mathrm{Nb}_{2} \mathrm{O}_{5} / \mathrm{SBA}-15$ catalyzed propanoic acid esterification. Appl Catal B Environ. 2017;205:498-504.

72. Liu G, Liao Y, Wu Y, Ma X. Synthesis gas production from microalgae gasification in the presence of $\mathrm{Fe}_{2} \mathrm{O}_{3}$ oxygen carrier and $\mathrm{CaO}$ additive. Appl Energy. 2018:212:955-65.

73. Liu X, Piao X, Wang Y, Zhu S, He H. Calcium methoxide as a solid base catalyst for the transesterification of soybean oil to biodiesel with methanol. Fuel. 2008;87:1076-82.

74. Gan Y, Qiao L. Combustion characteristics of fuel droplets with addition of nano and micron-sized aluminum particles. Combust Flame. 2011;158:354-68.

75. KreissI HT, Nakagawa K, Peng Y-K, Koito Y, Zheng J, Tsang SCE. Niobium oxides: correlation of acidity with structure and catalytic performance in sucrose conversion to 5-hydroxymethylfurfural. J Catal. 2016;338:329-39.

76. Sinha VK, Sharlin. A review approach on exhaust emission reduction by nanoparticle additives in diesel engine. Int J Innov Res Sci Eng Technol. 2017;6:15046-50

77. Silitonga, Masjuki HH, Ong HC, Sebayang A, Dharma S, Kusumo F, et al Evaluation of the engine performance and exhaust emissions of biodiesel-bioethanol-diesel blends using kernel-based extreme learning machine. Energy. 2018;159:1075-87.

78. Damanik N, Ong HC, Tong CW, Mahlia TMI, Silitonga AS. A review on the engine performance and exhaust emission characteristics of diesel engines fueled with biodiesel blends. Environ Sci Pollut Res Int 2018;25:15307-25.

79. Karthikeyan S. Environmental effects of nano additive $\mathrm{CO}_{3} \mathrm{O}_{4}$ in grape seed oil biofuel fuelled in Cl engine. Res J Chem Environ. 2014;18:14-8.

80. Karthikeyan S, Prabhakaran TD. Emission analysis of Botryococcus braunii algal biofuel using Ni-Doped $\mathrm{ZnO}$ nano additives for IC engines. Energ Source Part A. 2018;40:1060-7

81. Ong HC, Milano J, Silitonga AS, Hassan MH, Shamsuddin AH, Wang CT, et al. Biodiesel production from Calophyllum inophyllum-Ceiba pentandra oil mixture: optimization and characterization. J Clean Prod. 2019;219:183-98.

82. Dhinesh B, Annamalai M. A study on performance, combustion and emission behaviour of diesel engine powered by novel nano nerium oleander biofuel. J Clean Prod. 2018;196:74-83.

83. Jones M, Li CH, Afjeh A, Peterson G. Experimental study of combustion characteristics of nanoscale metal and metal oxide additives in biofuel (ethanol). Nano Res Lett. 2011;6:246.

84. Shaafi T, Sairam K, Gopinath A, Kumaresan G, Velraj R. Effect of dispersion of various nanoadditives on the performance and emission characteristics of a Cl engine fuelled with diesel, biodiesel and blendsa review. Renew Sust Energ Rev. 2015;49:563-73.

85. Kamiński W, Tomczak E, Górak A. Biobutanol_production and purification methods. Ecol Chem Eng. 2011;18:31-7.

86. Phwan CK, Ong HC, Chen W-H, Ling TC, Ng EP, Show PL. Overview: comparison of pretreatment technologies and fermentation processes of bioethanol from microalgae. Energy Convers Manag. 2018;173:81-94.

87. Shokrkar H, Ebrahimi S, Zamani M. Bioethanol production from acidic and enzymatic hydrolysates of mixed microalgae culture. Fuel. 2017;200:380-6.

88. Tsukahara K, Sawayama S. Liquid fuel production using microalgae. J Jpn Petrol Inst. 2005:48:251-9.

89. Hossain N, Zaini J, Jalil R, Mahlia TMI. The efficacy of the period of saccharification on oil palm (Elaeis guineensis) trunk sap hydrolysis. Int J Technol. 2018:9:652-62.

90. Ranjith Kumar R, Hanumantha Rao P, Arumugam M. Lipid extraction methods from microalgae: a comprehensive review. Front Energy Res. 2015;2:1-9.

91. Feltes MMC, de Oliveira D, Ninow JL, de Oliveira JV, editors. An overview of enzyme-catalyzed reactions and alternative feedstock for biodiesel production. New York: Federal University of Santa Catarina, Brazil; Intech; 2011.

92. Wang S, Zhu J, Dai L, Zhao X, Liu D, DuW. A novel process on lipid extraction from microalgae for biodiesel production. Energy. 2016;115:963-8.

93. Rahman MA, Aziz MA, Al-khulaidi RA, Sakib N, Islam M. Biodiesel production from microalgae Spirulina maxima by two step process: optimization of process variable. J Radiat Res Appl Sci. 2017:10:140-7.

94. Mohamadzadeh Shirazi H, Karimi-Sabet J, Ghotbi C. Biodiesel production from Spirulina microalgae feedstock using direct transesterification near supercritical methanol condition. Bioresour Technol. 2017;239:378-86.

95. Cheng J, Qiu Y, Huang R, Yang W, Zhou J, Cen K. Biodiesel production from wet microalgae by using graphene oxide as solid acid catalyst. Bioresour Technol. 2016:221:344-9.

96. Kings AJ, Raj RE, Miriam LRM, Visvanathan MA. Cultivation, extraction and optimization of biodiesel production from potential microalgae Euglena sanguinea using eco-friendly natural catalyst. Energy Convers Manag. 2017;141:224-35.

97. Pan Y, Alam MA, Wang Z, Huang D, Hu K, Chen H, et al. One-step production of biodiesel from wet and unbroken microalgae biomass using deep eutectic solvent. Bioresour Technol. 2017;238:157-63.

98. Ehimen EA, Sun ZF, Carrington CG, Birch EJ, Eaton-Rye JJ. Anaerobic digestion of microalgae residues resulting from the biodiesel production process. Appl Energy. 2011;88:3454-63.

99. Razon LF, Tan RR. Net energy analysis of the production of biodiesel and biogas from the microalgae: haematococcus pluvialis and nannochloropsis. Appl Energy. 2011;88:3507-14.

100. Silitonga AS, Masjuki HH, Ong HC, Mahlia TMI, Kusumo F. Optimization of extraction of lipid from /sochrysis galbana microalgae species for biodiesel synthesis. Energy Source Part A. 2017:39:1167-75.

101. Hu Z, Ma X, Li L, Wu J. The catalytic pyrolysis of microalgae to produce syngas. Energy Convers Manag. 2014;85:545-50.

102. Hong Y, Chen W, Luo X, Pang C, Lester E, Wu T. Microwave-enhanced pyrolysis of macroalgae and microalgae for syngas production. Bioresour Technol. 2017;237:47-56

103. Azadi P, Brownbridgea GPE, Mosbacha S, Inderwildib OR, Krafta M. Production of Biorenewable hydrogen and syngas via algae gasification: a sensitivity analysis. In: The 6th international conference on applied energy-ICAE2014: energy procedia; 2014. p. 2767-2770.

104. Beneroso D, Bermudez JM, Arenillas A, Menendez JA. Microwave pyrolysis of microalgae for high syngas production. Bioresour Technol. 2013;144:240-6.

105. Freitas ACD, Guirardello R. Thermodynamic analysis of supercritical water gasification of microalgae biomass for hydrogen and syngas production. Chem Eng Trans. 2013;32:553-8.

106. CuiY, Rashid N, Hu N, Rehman MSU, Han J-I. Electricity generation and microalgae cultivation in microbial fuel cell using microalgae-enriched anode and bio-cathode. Energy Convers Manag. 2014;79:674-80.

107. Khazraee ZM, Kariminia HR, Vosoughi M. Electricity generation, desalination and microalgae cultivation in a biocathode-microbial desalination cell. J Environ Chem Eng. 2017;5:843-8. 
108. Costa C, Hadiyanto A. Bioelectricity production from microalgae-microbial fuel cell technology (MMFC). MATEC Web Conf. 2018;156:2-4.

109. Stucki S, Vogel F, Ludwig C, Haiduc AG, Brandenberger M. Catalytic gasification of algae in supercritical water for biofuel production and carbon capture. Energy Environ Sci. 2009;2:535.

110. Liu C-H, Chang C-Y, Liao Q, Zhu X, Liao C-F, Chang J-S. Biohydrogen produCtion by a novel integration of dark fermentation and mixotrophic microalgae cultivation. Int J Hydrog Energy. 2013;38:15807-14.

111. Molino A, Nanna F, Ding Y, Bikson B, Braccio G. Biomethane production by anaerobic digestion of organic waste. Fuel. 2013;103:1003-9.

112. Gruber-Brunhumer MR, Jerney J, Zohar E, Nussbaumer M, Hieger C, Bromberger P. Associated effects of storage and mechanical pre-treatments of microalgae biomass on biomethane yields in anaerobic digestion. Biomass Bioenergy. 2016;93:259-68.

113. Visceral. Biophotolysis: green hydrogen fuel production: Daily Kos. 2008. http://www.dailykos.com/story/2008/6/27/543096/-

114. Carrillo-Reyes J, Buitron G. Biohydrogen and methane production via a two-step process using an acid pretreated native microalgae consortium. Bioresour Technol. 2016;221:324-30.

115. Tapia-Venegas E, Ramirez-Morales JE, Silva-Illanes F, Toledo-Alarcón J, Paillet F, Escudie R. Biohydrogen production by dark fermentation: scaling-up and technologies integration for a sustainable system. Rev Environ Sci Biotechnol. 2015;14:761-85.

116. Rashid N, Rehman MSU, Memon S, Rahman ZU, Lee K, Han Jl. Current status, barriers and developments in biohydrogen production by microalgae. Renew Sustain Energ Rev. 2013;22:571-9.

117. Ma Z, Li C, Su H. Dark bio-hydrogen fermentation by an immobilized mixed culture of Bacillus cereus and Brevumdimonas naejangsanensis. Renew Energ. 2017;105:458-64.

118. Nagarajan D, Lee DJ, Kondo A, Chang JS. Recent insights into biohydrogen production by microalgae from biophotolysis to dark fermentation. Bioresour Technol. 2016;227:373-87.

119. Elliott DC, Biller P, Ross AB, Schmidt AJ, Jones SB. Hydrothermal liquefaction of biomass: developments from batch to continuous process. Bioresour Technol. 2015;178:147-56.

120. Yu KL, Show PL, Ong HC, Ling TC, Chi-Wei Lan J, Chen WH, et al. Microalgae from wastewater treatment to biochar-feedstock preparation and conversion technologies. Energy Convers Manag. 2017;150:1-13.

121. Yu KL, Lau BF, Show PL, Ong HC, Ling TC, Chen W-H, et al. Recent developments on algal biochar production and characterization. Bioresour Technol. 2017;246:2-11.
122. Chaiwong K, Kiatsiriroat T, Vorayos N, Thararax C. Study of bio-oil and bio-char production from algae by slow pyrolysis. Biomass Bioenergy. 2013;56:600-6.

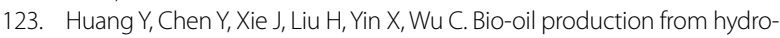
thermal liquefaction of high-protein high-ash microalgae including wild Cyanobacteria sp. and cultivated Bacillariophyta sp. Fuel. 2016;183:9-19.

124. Zainan NH, Srivatsa SC, Li F, Bhattacharya S. Quality of bio-oil from catalytic pyrolysis of microalgae Chlorella vulgaris. Fuel. 2018;223:12-9.

125. Chang Z, Duan P, Xu Y. Catalytic hydropyrolysis of microalgae: influence of operating variables on the formation and composition of bio-oil. Bioresour Technol. 2015;184:349-54

126. Shamsul NS, Kamarudin SK, Rahman NA. Conversion of bio-oil to bio gasoline via pyrolysis and hydrothermal: a review. Renew Sust Energ Rev. 2017:80:538-49.

127. Ferreira A, Soares Dias A, Silva C, Costa M. Bio-oil and bio-char characterization from microalgal biomass. In: V Conferência Nacional de Mecânica dos Fluidos, Termodinâmica e Energia; 11-12 September, 2014; Porto, Portugal. 2014. p. 99-104.

128. Pandian AK, Ramakrishnan RBB, Devarajan Y. Emission analysis on the effect of nanoparticles on neat biodiesel in unmodified diesel engine. Environ Sci Pollut Res Int. 2017;24:23273-8.

129. Basha JS, Anand RB. The influence of nano additive blended biodiesel fuels on the working characteristics of a diesel engine. J Braz Soc Mech Sci. 2013:35:257-64.

130. Krishna VSR, Reddy KVK, Prasad BD. Experimental investigations on LHR diesel engine using biodiesel with nano additive. Int J Lat Eng Manag Res. 2018:3:89-95.

131. Wang SK, Wang F, Hu YR, Stiles AR, Guo C, Liu CZ. Magnetic flocculant for high efficiency harvesting of microalgal cells. ACS Appl Mater Inter. 2014;6:109-15.

132. Lee K, Lee SY, Na JG, Jeon SG, Praveenkumar R, Kim DM, et al. Magnetophoretic harvesting of oleaginous Chlorella sp. by using biocompatible chitosan/magnetic nanoparticle composites. Bioresour Technol. 2013;149:575-8.

\section{Publisher's Note}

Springer Nature remains neutral with regard to jurisdictional claims in published maps and institutional affiliations.
Ready to submit your research? Choose BMC and benefit from:

- fast, convenient online submission

- thorough peer review by experienced researchers in your field

- rapid publication on acceptance

- support for research data, including large and complex data types

- gold Open Access which fosters wider collaboration and increased citations

- maximum visibility for your research: over $100 \mathrm{M}$ website views per year

At BMC, research is always in progress.

Learn more biomedcentral.com/submissions 